\title{
Fertility studies of complementing genotypes at the albino locus of the mouse
}

\author{
Susan E. Lewis*, H. A. Turchin and Theresa E. Wojtowicz \\ Department of Genetics, Albert Einstein College of Medicine, New York, New York 10461, U.S.A.
}

\begin{abstract}
Summary. Mice doubly heterozygous for two radiation-induced lethal alleles at the albino locus $\left(c^{3 H}\right.$ and $c^{6 H}$ ) show partial complementation: they are viable but runted and sterile. In $c^{3 H} / c^{6 H}$ females oogenesis and mating are normal, but nearly all of their fetuses, even when genotypically normal $\left(+/ c^{3 H}\right.$ or $\left.+/ c^{6 H}\right)$, fail to survive beyond midgestation. Abnormalities of spermatogenesis, i.e. morphological defects in head condensation and a deficiency in numbers of maturing spermatids, are histologically detectable in the testes of $c^{3 H} / c^{6 H}$ males. Spermatozoa from the vasa deferentia of such males are predominantly nonviable, immotile, and grossly abnormal in morphology.
\end{abstract}

\section{Introduction}

Several radiation-induced deletion alleles at the albino locus in the mouse are associated with a variety of biochemical, morphogenetic, and ultrastructural defects in homozygotes (Erickson, Gluecksohn-Waelsch \& Cori, 1968; Thorndike, Trigg, Stockert \& Gluecksohn-Waelsch, 1973; Trigg \& Gluecksohn-Waelsch 1973; Lewis, Turchin \& Gluecksohn-Waelsch, 1976), Doubly heterozygous partial complementers are viable but runted and sterile (Gluecksohn-Waelsch, Schiffman, Thorndike \& Cori, 1974). This report presents an analysis of several aspects of reproduction in sterile complementers of both sexes.

Sterile males doubly heterozygous for alleles at the albino locus showed effects on sperm morphology similar to those found in males of various pink sterile genotypes (Hunt \& Johnson, 1971) and we therefore examined possible interactions between albino and pink-eyed alleles.

\section{Materials and Methods}

Because the radiation-induced alleles used in this study $\left(c^{3 H}\right.$ and $\left.c^{6 H}\right)$ are lethal when homozygous, they must be maintained in the heterozygous state. Carriers of these alleles, $c^{c h} / c^{3 H}$ and $c^{c h} / c^{6 H}$ mice, can be distinguished from homozygous chinchilla littermates $\left(c^{c h} / c^{c h}\right)$ by their more dilute coat colour. Interline crosses of $c^{3 H}$ and $c^{6 H}$ heterozygotes were used to produce partly complementing $c^{3 H} / c^{6 H}$ double heterozygotes, which are viable and easily recognizable by their albino phenotype. Heterozygous dilute $\left(c^{c h} / c^{*}\right)$ or homozygous chinchilla $\left(c^{c h} / c^{c h}\right)$ sibs were used for controls.

Tests of interaction of the pink-sterile with albino alleles were carried out by crossing $c^{6 \mathrm{H}}$ heterozygotes $\left(c^{c h} / c^{6 H}\right)$ with carriers of the $p^{\sigma H}$-sterile allele $\left(p^{d} / p^{\sigma H}\right) . \mathrm{F}_{1}$ males were then progeny tested with viable albino $(c / c)$ and fertile pink females $\left(p^{u n} / p^{u n}\right)$ to determine whether they carried the relevant allele, i.e. $c^{6 H}$ and $p^{6 H}$, at both loci.

All $c^{3 H} / c^{6 H}$ complementers and the control sibs were mated to unrelated wild-type $(+/+)$ mice from other strains and the animals were checked twice daily for vaginal plugs. Complementer and control females were killed 10-14 days after at the appearance of vaginal plugs (= Day 1 of pregnancy).

For the sperm studies, spermatozoa were stripped from the vasa deferentia of $c^{3 H} / c^{6 H}$ and control males into saline $(0.15 \mathrm{M}-\mathrm{NaCl})$. Motility was rated qualitatively on a scale of 0 to ++++ . Viability was assessed by counting 100 spermatozoa from each animal: sperm smears were stained with the vital

* Present address: Department of Human Genetics, University of Michigan Medical School, Ann Arbor, Michigan 48109, U.S.A. 
stain brilliant cresyl blue and dye exclusion was used as an index of viability. Morphological variations were examined in dry smears with phase microscopy and 200 spermatozoa from each male were classified.

Ovaries were fixed in Bouin's fluid for histological analysis, sectioned at $8 \mu \mathrm{m}$, and stained in haematoxylin and eosin. Testes and epididymides were fixed in Zenker-formol and sectioned at $6 \mu \mathrm{m}$. Sections were stained with periodic acid-Schiff reagent and counterstained with Celestine blue and alum haematoxylin (Drury \& Wellington, 1967).

Kinetics of spermatogenesis in three $c^{3 H} / c^{6 H}$ males were compared to those in three control adult males. For each animal 4-6 cross-sections, $100 \mu \mathrm{m}$ apart, of the testes were scanned. The stage of spermatogenesis in each of 250 seminiferous tubules was determined on the basis of the morphology of the PAS-stained spermatids (Oakberg, 1956), and the nuclei of each cell class were counted. This analysis of spermatogenesis was restricted to stages 1 to 8 because of the difficulty of counting accurately the spermatids of later stages. Abercrombie's correction factor was used for calculations of frequencies of cell types (Abercrombie, 1946).

\section{Results}

\section{Female fertility}

The ovarian histology of $c^{3 H} / c^{6 H}$ females was essentially normal with all stages of oogenesis and folliculogenesis present. Corpora lutea in the ovaries of two $c^{3 H} / c^{6 H}$ females in earlystages of pregnancy were indistinguishable from those of normal females. However, the litter size at implantation was significantly lower $\left(P<0.01\right.$, Student's $t$ test) in $c^{3 H} / c^{6 H}$ females than in control females (Table 1) and most of the offspring of $c^{3 H} / c^{6 H}$ females were resorbed by 10-14 days of gestation. There were no detectable morphological abnormalities of the dead and resorbing embryos. Furthermore, none of the progeny of $\operatorname{six~} c^{3 H} / c^{6 H}$ females allowed to go to term survived until birth.

Table 1. Comparison of the fertility of $c^{3 H} / c^{6 H}$ and $c^{c h} / c^{*}$ (control) female mice killed at 10-14 days of gestation

\begin{tabular}{lccccc}
\hline Genotype & $\begin{array}{c}\text { No. of } \\
\text { litters }\end{array}$ & $\begin{array}{c}\text { Total no. } \\
\text { of embryos }\end{array}$ & $\begin{array}{c}\text { No. of living } \\
\text { embryos* }\end{array}$ & $\begin{array}{c}\text { No. of dead and } \\
\text { resorbed embryos (\%) }\end{array}$ & $\begin{array}{c}\text { Litter size } \\
\text { (mean } \pm \text { s.e.m.) }\end{array}$ \\
\hline$c^{3 H} / c^{6 H}$ & 8 & 43 & 11 & $32(74)$ & $5.4 \pm 1.6$ \\
$c^{c h} / c^{*}$ & 7 & 69 & 67 & $2(3)$ & $9.9 \pm 0.9$ \\
\hline
\end{tabular}

* Determined by the presence of a heartbeat.

\section{Epididymal spermatozoa}

A summary of the characteristics of $c^{3 H} / c^{6 H}$ spermatozoa is presented in Table 2. The spermatozoa from most of the complementers stained and were therefore deemed nonviable; a low sperm viability of $20-50 \%$ was observed for only three $c^{3 H} / c^{6 H}$ males. The motility of the spermatozoa from the complementers was also severely affected: instead of the propulsive motions of normal spermatozoa the $c^{3 H} / c^{6 H}$ spermatozoa showing any movement merely quivered or twitched erratically.

Table 2. Summary of characteristics of spermatozoa from the vas deferens of $c^{3 H} / c^{6 H}$ and control mice (no. in parentheses)

\begin{tabular}{lccc}
\hline Genotype & Motility score & $\%$ viability & $\begin{array}{c}\% \text { with abnormal } \\
\text { morphology }\end{array}$ \\
\hline $\begin{array}{l}c^{3 H} / c^{6 H} \\
c^{c h} / c^{*} \\
\begin{array}{l}\text { and } \\
c^{c h} / c^{c h} \text { sibs }\end{array}\end{array}$ & $0-+(25)$ & $0-50(17)$ & $42-99(8)$ \\
\hline
\end{tabular}


The frequency of morphologically abnormal spermatozoa (Plate 1) from complementer males was very high. Most of the defects were of the 'clubheaded' type (Pl. 1, Fig. 2), although multi-tailed and filamentous types were also found (Pl. 1, Figs 3 and 4). In addition, sperm suspensions from complementer males typically had a large excess of cellular debris.

\section{Kinetics of spermatogenesis}

As shown in Text-fig. 1 the kinetics of spermatogonial differentiation in the testes of $c^{3 H} / c^{6 H}$ males was the same in every respect as in those of control animals, and the numbers of type $A$ and total spermatogonia were comparable at all stages. The numbers of primary spermatocytes at all stages of the spermatogenic cycle and spermatids of stages $1-8$ were significantly reduced $(P<0 \cdot 01$, Student's $t$ test) in the seminiferous tubules of complementers compared to those in the controls (Text-fig. 2).

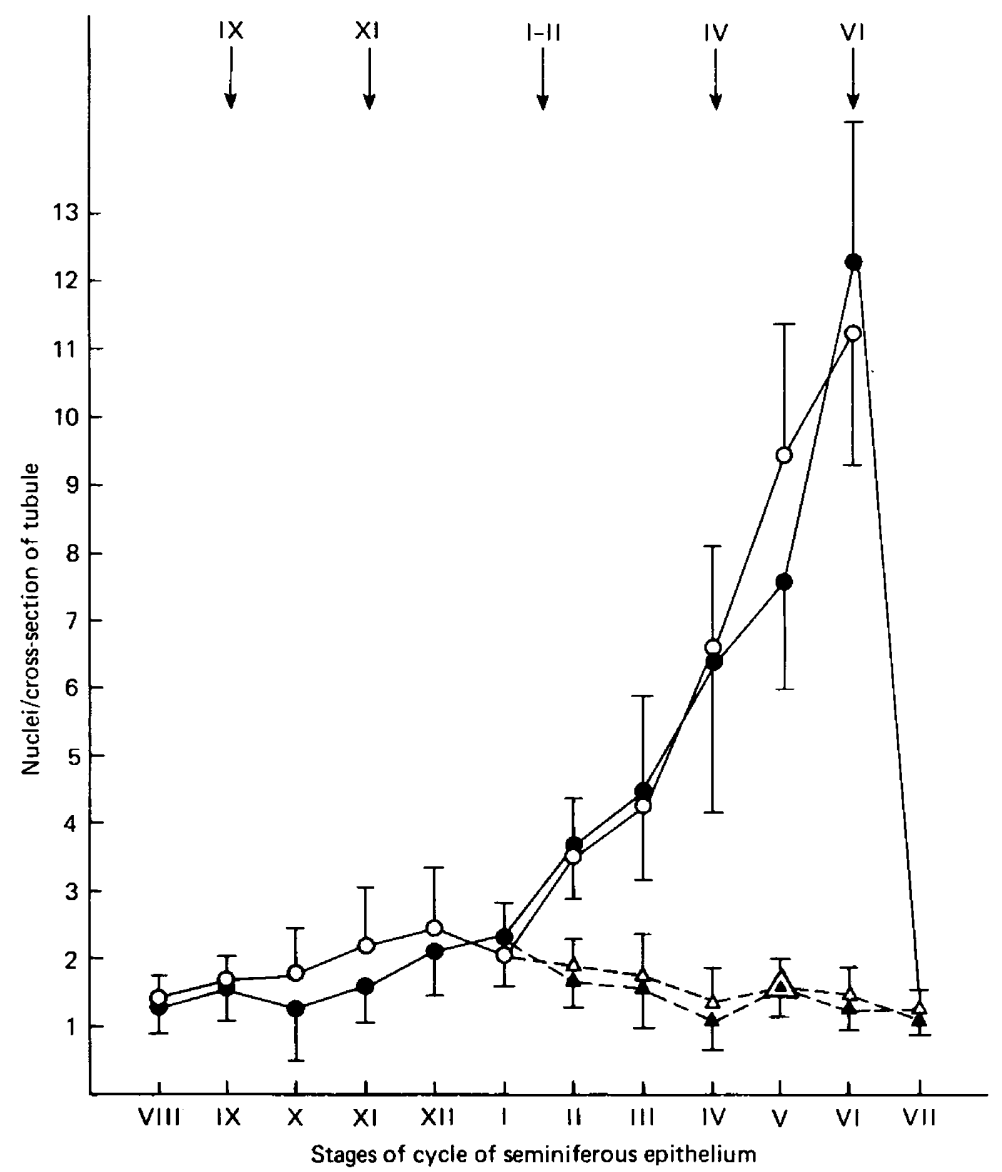

Text-fig. 1. A comparison of the mean ( \pm s.e.m.) number of total $(\bullet, 0)$ and type $A(\Delta, \Delta)$ spermatogonia in cross-sections of seminiferous tubules of all stages in the testes of $c^{3 H} / c^{6 H}(O, \Delta)$ and control $(\bullet, A)$ males. Arrows indicate the stages of mitotic divisions.

\section{Testicular histology}

Large gaps among spermatocytes in the seminiferous tubules of all stages were quite common in the testes of complementers (PI. 2, Fig. 5), but were rarely seen in control testes (Pl. 2, Fig. 6). The cytology of mutant spermatogonia and primary spermatocytes was indistinguishable from normal. In general, stage 1-12 spermatids appeared histologically normal, but at stage 13 and later most of the 
sperm heads were vacuolated, apparently abnormally condensed and clearly abnormal in shape (Pl. 2 , Figs 5 and 7) when compared to spermatids from control tubules (Pl. 2, Fig. 8). Maturing spermatids from normal animals were organized into distinct bundles (Pl. 2, Fig. 6) but organization was totally lacking in the seminiferous tubules of sterile double heterozygotes (Pl. 2, Figs 5 and 7). Interstitial cells and Sertoli cells appeared histologically normal in the testes of sterile males. In contrast to the epididymides of control animals, which contain many maturing spermatozoa (Pl. 2, Fig, 9), the epididymal lumina of $c^{3 H} / c^{6 H}$ males contained large numbers of degenerating cells, many large PASpositive granules, and very few mature spermatozoa (PI. 2, Fig. 10).

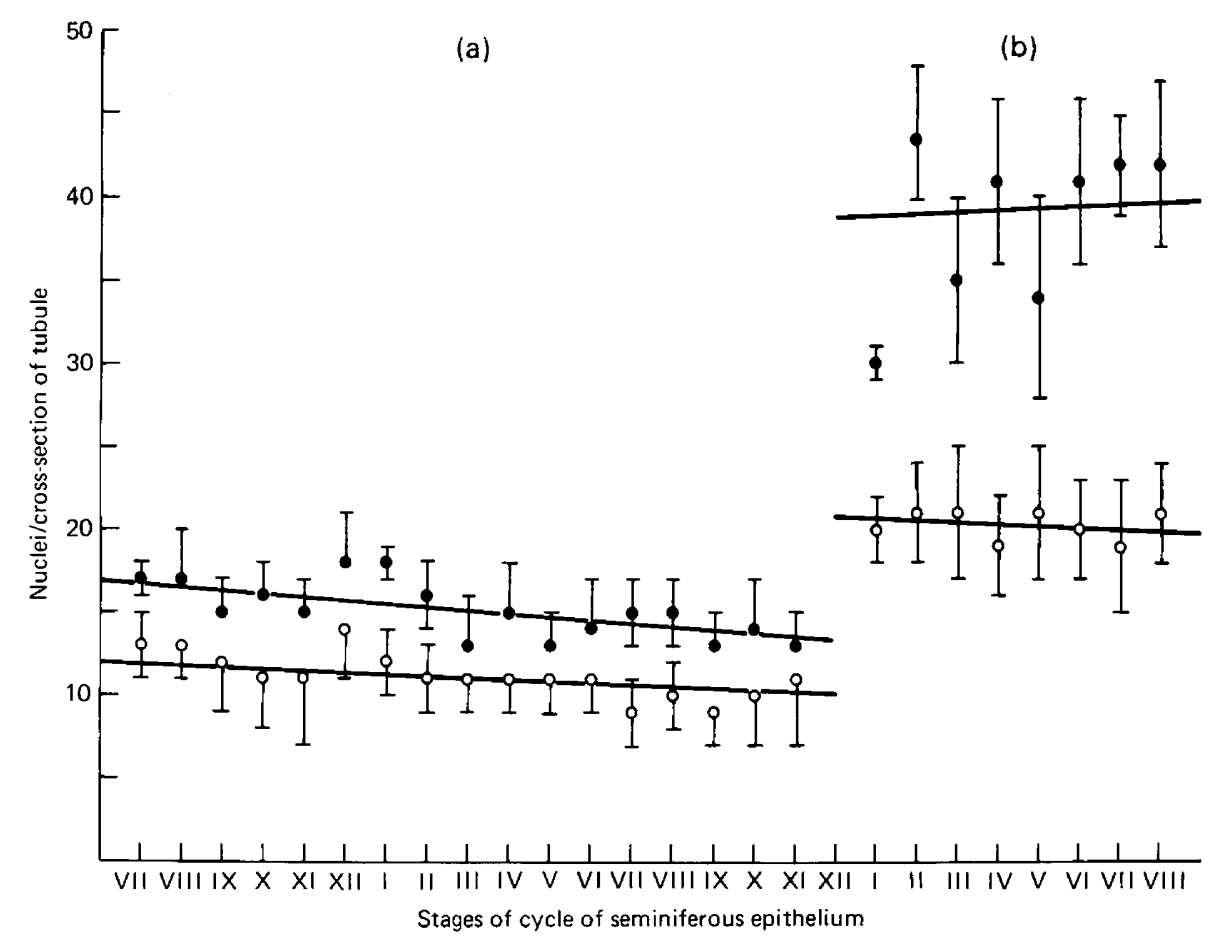

Text-fig. 2. The mean ( \pm s.e.m.) number of (a) primary spermatocytes in the seminiferous tubules at all stages and (b) spermatids at stages $1-8$ in the testes of control $(\bullet)$ and $c^{3 H} / c^{6 H}(O)$ mice.

\section{Interactions between pink- and albino-sterile alleles}

Interline crosses of carriers of pink- and albino-sterile alleles $\left(C / C p^{d} / p^{6 H} \times c^{c h} / c^{6 H} P / P\right)$ produced 4 males which were shown by progeny tests to be $P / p^{6 H} C / c^{6 H}$. All of these males were fully fertile, and spermatozoa from the vas deferens had entirely normal viability, motility and morphology. There is therefore no interaction between pink- and albino-sterile alleles in producing effects on male reproduction.

\section{Discussion}

The examination of gametogenesis in partially complementing sterile mice doubly heterozygous for two lethal albino alleles $\left(c^{3 H} / c^{6 H}\right)$ reveals different mechanisms of sterility in the two sexes. Oogenesis is histologically normal in $c^{3 H} / c^{6 H}$ females. They are able to conceive and support the development of at least some of their embryos to postimplantation stages. However, all of their progeny die before birth, usually at mid-gestation. Since these embryos are genotypically normal $\left(+/ c^{*}\right)$ and pregnancy is entirely normal in control female sibs, the gestational failure must be due to the $c^{3 H} / c^{6 H}$ genotype 
PLATE 1
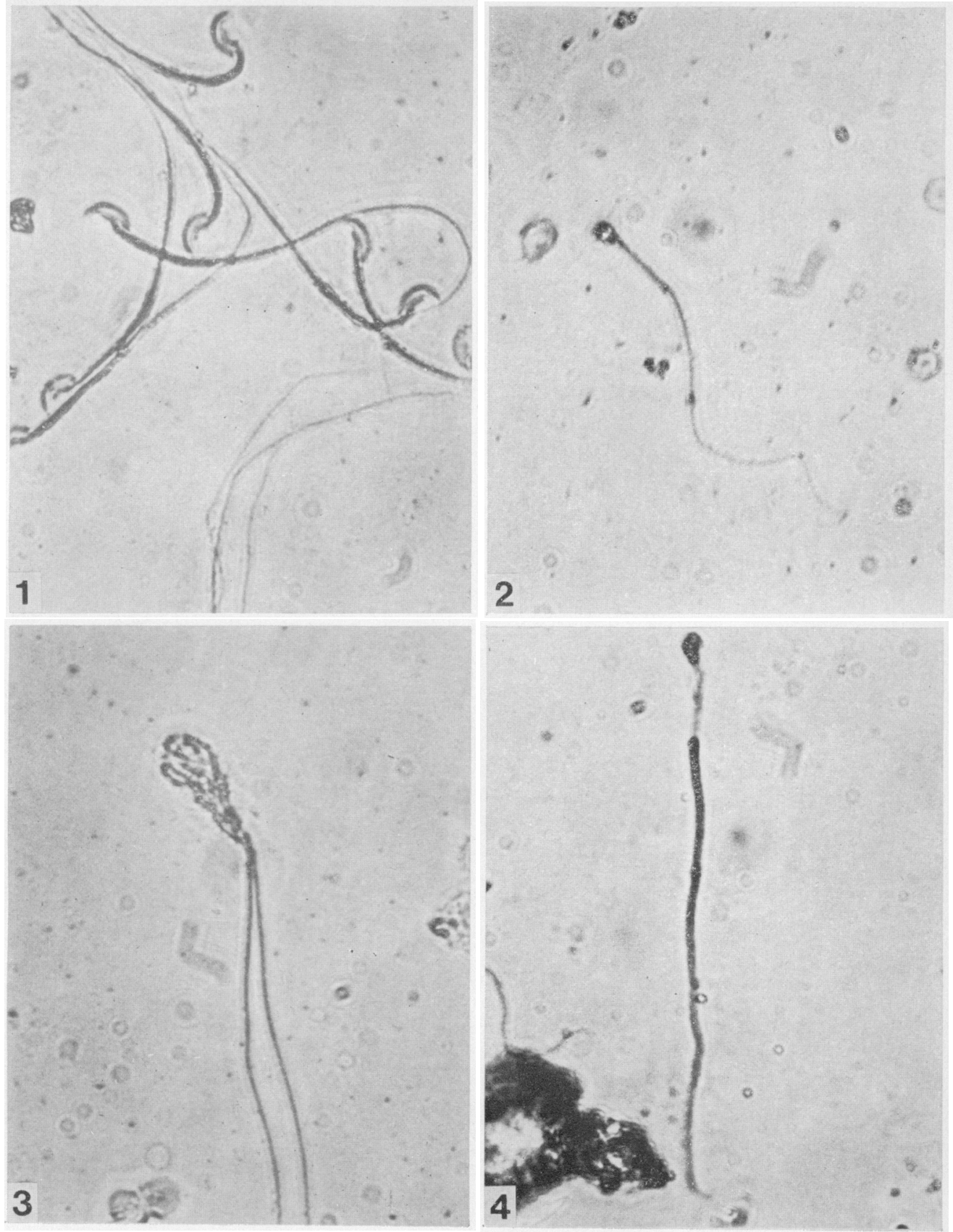

Dry smears of spermatozoa from the vas deferens. $\times 475$.

Fig. 1. Morphologically normal spermatozoa from a control male.

Fig. 2. 'Club-headed' spermatozoon from a $c^{3 H} / c^{6 H}$ male.

Fig. 3. Double-tailed spermatozoon with grossly misshapen head from a $c^{3 H} / c^{6 H}$ male.

Fig. 4. 'Filamentous' spermatozoon from a $c^{3 H} / c^{6 H}$ male. 

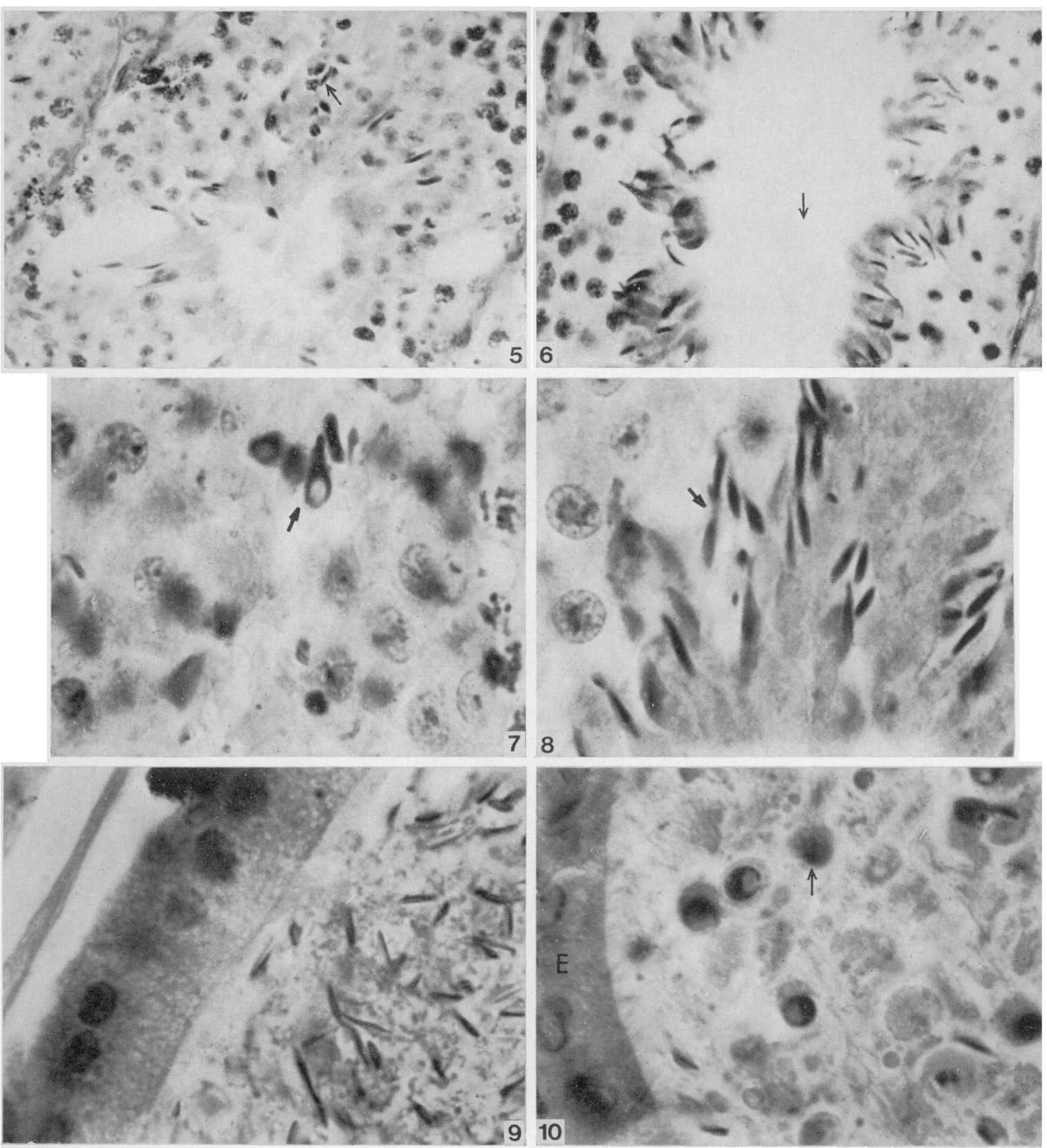

Fig. 5. Stage I seminiferous tubules from a $c^{3 H} / c^{6 H}$ male. Note the large gaps in the seminiferous epithelium. Arrow indicates stage 13 vacuolated spermatids. PAS, Celestine blue, haemalum; $5 \mu \mathrm{m}$ section, $\times 375$.

Fig. 6. Stage I seminiferous tubule from a control male. Arrow indicates the lumen of the tubule. Note the organized bundles of maturing spermatids. PAS, Celestine blue, haemalum; $5 \mu \mathrm{m}$ section, $\times 375$.

Fig. 7. Stage I seminiferous tubules from the testis of a $c^{6 H} / c^{\circ H}$ male. Arrow indicates a group of abnormally shaped stage 13 spermatids, including one with a large vacuole. $\times 935$.

Fig. 8. Stage I seminiferous tubules from a testis of a control male. Arrow indicates normal stage 13 spermatids. $\times 935$.

Fig. 9. Epididymis of a control male. Note the large number of normal sperm heads in the lumen. $\times 935$.

Fig. 10. Epididymis of a $c^{3 H} / c^{6 H}$ male. Arrow indicates cellular debris in lumen. The epithelium (E) is normally ciliated. $\times 935$. 
of the mother. Adverse maternal effects on embryonic survival have also been reported in females of the DDK strain in which there is a high incidence of early embryonic death among offspring of certain outcrosses (Wakasugi, 1973). The causes of such genetically controlled maternal effects on development are as yet unknown but they serve to emphasize the importance of the genome affecting maternal environment in normal mammalian development.

In contrast to the complementer females, gametogenesis in $c^{3 H} / \mathrm{c}^{6 H}$ males is disturbed and grossly abnormal spermatids result. The numbers of spermatogonia and the kinetics of their further differentiation are indistinguishable from those of control males. Meiosis appears to proceed normally in spite of a slight depression in the numbers of primary spermatocytes. Although there is a significant deficiency of maturing spermatids at earlier stages, the first detectable morphological abnormality of spermatids during spermiogenesis in $c^{3 H} / c^{6 H}$ males appears at stage 13 and involves abnormal head condensation.

The onset and nature of the visible defects in $c^{3 H} / c^{6 H}$ spermatogenesis are similar to those reported for sterile quaking homozygotes (Bennet et al., 1971). The pleiotropic effects in $q k / q k$ animals include defects of fatty acid elongation in the nervous system (Goldberg, Schechter \& Bloch, 1973) and of the lipid composition of other organs (Kishimoto, 1970). The $c^{3 H} / c^{6 H}$ mice have no mitochondrial malic enzyme because of the deletion of the mod-2 locus in both of these alleles (Erickson, Eicher \& Gluecksohn-Waelsch, 1974; E. M. Eicher, unpublished results). Although the function of the mitochondrial malic enzyme has not been conclusively established, it is believed to be involved in the reductive biosynthesis of fatty acids (Frenkel, 1975). The similarity of the effects on spermatogenesis in sterile quaking and albino mutants and the possible genetic control of lipid metabolism by the two loci might suggest a similar molecular defect.

However, the morphological abnormalities of the epididymal spermatozoa and the detectable defects in spermatogenesis of $c^{3 H} / c^{6 H}$ males strongly resemble those of males homozygous for certain pink-eyed dilution sterile alleles (Hollander, Bryan \& Gowen, 1960; Hunt \& Johnson, 1971; Wolfe, Erickson \& Schmidt, 1977). The albino- and pink-eyed loci are further related by linkage (14 map units) and effects on pigmentation, but the present study of interactions of sterile alleles at these loci reveal full fertility and entirely normal epididymal spermatozoa of $P / p^{6 H} C / c^{6 H}$ males.

The association of genetic effects of lethal albino alleles on embryonic development (Lewis et al., 1976) and on reproduction is reminiscent of the complex $T$-locus where embryonic lethality as well as male sterility can result from certain combinations of alleles (Gluecksohn-Waelsch \& Erickson, 1970; Bennett, 1975). In common with the sterile effects in lethal albino partial complementers, males partially complementing for certain recessive lethal alleles at the $T$-locus are also sterile (Braden \& Gluecksohn-Waelsch, 1958). Furthermore, males homozygous for $t^{w 2}$ (Dooher \& Bennett, 1974) and $\boldsymbol{t}^{A E s}$ (Vojtiskova, Viklicky, Vorocova, Lewis \& Gluecksohn-Waelsch, 1976) appear to have specific defects in spermiogenesis. These similarities between the effects mediated by two complex loci may indicate a relationship between the genetic control of development and that of reproduction.

Any attempts to analyse the effects of the radiation induced-lethal alleles at the albino locus must take into account the fact that they are deletions which include more than one genetic locus. Nevertheless, these deletion alleles may offer an opportunity for a causal analysis of reproduction and development and the possible interrelationship between them.

We thank Dr Salome Gluecksohn-Waelsch for guidance and encouragement during the course of this study; Dr Robert P. Erickson for helpful discussion and careful reading of the manuscript; and Dr Glenn Wolfe for his gift of $p^{d} / p^{6 H}$ and $p^{u n} / p^{u n}$ mice. This research was supported by grants from NIH (GM-00110, HD-00193, GM-19100) and from the American Cancer Society (VC-64 to Dr S. Gluecksohn-Waelsch).

\section{References}

Abercrombie, M. (1946) Estimations of nuclear populations from microtome sections. Anat. Rec. 84, 239-247.

Bennetr, D. (1975) The $T$-locus of the mouse. Cell 36, $441-454$.
Bennetr, W.I., Gall, A.M., Southard, J.L. \& Sidman, R.I. (1971) Abnormal spermiogenesis in quaking a myelin-deficient mutant mouse. Biol. Reprod. 5, 3958. 
Braden, A.W.H. \& Gluecksohn-Waelsch, S. (1958) Further studies on the effect of the $T$-locus in the house mouse on male fertility. J. exp. Zool. 183, 431452.

Dooher, G.B. \& BennetT, D. (1974) Abnormal microtubular systems in mouse spermatids associated with a mutant gene at the T-locus. J. Embryol.exp. Morph. 32, 749-761.

Drury, R.A. \& Wellington, E.A. (1967) Carleton's Histological Technique, 4th edn. Oxford University Press, New York.

Erickson, R.P., Gluecksohn-WAelsch, S.\& Cori, C.F. (1968) Glucose-6-phosphatase deficiency caused by radiation-induced alleles at the albino locus in the mouse. Proc. natn. Acad. Sci. U.S.A. 50, 437-444.

Erickson, R.P., EICHER, E.M. \& GLUECKSOHNWaElsch, S. (1973) Demonstration in the mouse of $x$-ray induced deletions for a known enzyme structural locus. Nature, Lond. 248, 416-418.

Frenkel, R. (1975) Regulation and physiological functions of malic enzymes. Current Topics Cell Regulat. 9, 157-181.

Gluecksohn-Waelsch, S. \& Erickson, R.P. (1970) The $T$-locus of the mouse: implications for mechanisms of development. Current Topics Devl Biol. 5, 281-316.

Gluecksohn-Waelsch, S., Schiffman, M.B., ThorNDIKE, J. \& CORI, C.F. (1974) Complementation studies of lethal alleles in the mouse causing deficiencies of glucose-6-phosphatase, tyrosine amino transferase and serine dehydratase. Proc. natn. Acad. Sci. U.S.A. $71,825-829$.

Goldberg, I., Schechter, I. \& Bloch, K. (1973) Fattyacyl-coenzyme $A$ elongation in brain of normal and quaking mice. Science, $N$. Y. 182, 497-499.

Hollander, W.F., Bryan, J.H.D. \& Gowen, J.W. (1960) A male sterile pink-eyed mutant type in the mouse. Fert. Steril. 11, 316-324.
Hunt, D.M. \& Johnson, D.R. (1971) Abnormal spermiogenesis in two pink-eyed sterile mutants in the mouse. J. Embryol. exp. Morph. 26, 111-121.

Kishimoto, A. (1970) Lipids of peripheral tissues from the quaking mouse. Fedn Proc. Fedn Am. Socs exp. Biol. 29, 894, Abstr.

Lewis, S.E., Turchin, H. \& Gluecksohn-Waelsch, S. (1976) The developmental analysis of an embryonic lethal $\left(c^{6 \mathbf{H}}\right)$ in the mouse. J. Embryol. exp. Morph. 36, 363-371.

OAKBERG, E.F. (1956) A description of spermiogenesis in the mouse and its use in analysis of the cycle of the seminiferous epithelium and germ cell renewal. Am.J. Anat. 99, 391-413.

Thorndike, J., Trigg, M.J., Stockert, R. \& GluecksohN-Waelsch, S. (1973) Multiple biochemical effects of a series of $x$-ray induced mutations at the albino locus in the mouse. Biochem. Genet. 8 , 25-39.

Trigg, M. \& Gluecksohn-Waelsch, S. (1973) Ultrastructural basis of biochemical effects in a series of lethal alleles in the mouse. J. Cell Biol 58, 549-563.

VoITISKOVA, M., VIKLICKY, V., VorocoVa, B., LeWIS, S.E. \& Gluecksohn-WaelsCh, S. (1976) The effects of a $t$-allele $\left(t^{A E S}\right)$ in the mouse on the lymphoid, system and reproduction.J. Embryol. exp. Morph. 36, $443-451$.

WAKASUGI, N. (1973) Studies on fertility of DDK mice: reciprocal crosses between DDK and C56B1/6J strains and experimental transplantation of the ovary. J. Reprod. Fert. 33, 283-291.

Wolfe, G., Erickson, R.P. \& SchmidT, L.C. (1977) Effects on sperm morphology by alleles at the pinkeyed dilution locus in mice. Genetics, Princeton $\mathbf{8 5}$ 303-308.

Received 4 June 1977 